\title{
SMART VILLAGE AND SUSTAINABILITY. SOUTHERN MORAVIA CASE STUDY
}

\author{
Antonín Vaishar, Milada Št'astná ${ }^{1}$
}

Received 29 August 2019, Revised 1 September 2019, Accepted 9 October 2019

\begin{abstract}
The paper is aimed at an attempt to define a smart village in the Czech conditions. It argues that the principles of smart villages are very similar to the concept of sustainability. The analysis deals with preventing rural exclusion, promoting digital technologies for the management of the rural infrastructure, teleworking in rural areas and using ICT for participation and governance. This approach is documented in the case of the SouthMoravian Region. It was concluded that it was not so much coverage or accessibility of digital technology that was the main barrier of more intensive use of the smart village concept but rather the lower qualification level and conservatism of rural population is. It is suggested that more attention should be paid to increasing the digital literacy of rural people.
\end{abstract}

Keywords: smart village, digital technologies, sustainability, South Moravia

Souhrn: Příspěvek je zaměřen na pokus definovat inteligentní vesnici v českých podmínkách. Tvrdí, že zásady inteligentních vesnic jsou velmi podobné konceptu udržitelnosti. Analýza se zabývá ochranou před vyloučením z venkova, digitálními technologiemi pro správu venkovské infrastruktury, prací na dálku ve venkovských oblastech a využíváním IKT $\mathrm{k}$ účasti a správě. Tento přistup je dokumentován $v$ př́padě Jihomoravského kraje. Dospělo se k závěru, že hlavní překážkou intenzivnějšího využívání konceptu inteligentní vesnice není pokrytí či dostupnost digitální technologie, ale nižší úroveň kvalifikace a konzervatismus venkovského obyvatelstva. Navrhuje se věnovat více pozornosti nárůstu digitální gramotnosti venkovských lidí.

Klíčová slova: inteligentní vesnice, digitální technologie, udržitelnost, jižní Morava

\section{Introduction}

The concept of a smart city is currently fashionable. It usually concerns a city which is connected by different kinds of digital technologies. However, a shared definition of smart city is not available and it is hard to identify common global trends (Neirotti et al., 2014). Some authors bring in mind that a smart city is not only a question of technology but it is necessary to take into account a holistic, integrated and multi-criteria approach (Zubizaretta, Seravalli and Arrizabalage, 2016).

\footnotetext{
1 Doc. RNDr. Antonín Vaishar, CSc., ORCID: 0000-0003-3754-7600, e-mail: antonin.vaishar@mendelu.cz; Prof. Ing. Milada Št’astná, Ph.D., ORCID: 0000-0002-4507-6207, e-mail: stastna@mendelu.cz, Department of Applied and Landscape Ecology, Faculty of AgriSciences, Mendel University in Brno, Czechia.
} 
Monzon (2017) points out that ICT within a smart city should be directed to a more efficient and sustainable city.

The challenge of smart villages is recognised by the EU (Zavratnik et al., 2018). The Declaration for a Smarter Future of the Rural Areas in the EU was accepted in Bled in April of 2018. Accordingly, the Smart Villages initiative aims to create rural areas where people can and want to live because innovative, digital solutions make their lives easy and comfortable. The Smart Village Network has been created to further this purpose. It connects about 20 local associations, most often represented by LEADER local action groups.

However, the idea of a smart village poses a number of challenges. Is a village only a minimalized city in this sense? The difference between cities and villages seems to consist of concentration (of people, goods, activities, waste, information, etc.) in cities and low density and remoteness in the countryside. Is it therefore possible to find a concept of a smart villagethat goes beyond this? Will this concept be based also on using digital technologies? Would it be possible to overcome some disadvantages of rural use through digital technologies?

Our paper is aimed at a discussion about the potential for an application of the smart villages approach, which could be found in the rural area of the South-Moravian NUTS3 region.

\section{Smart village (concept, definition, theory)}

In European conditions, smart is usually connected with knowledge and innovations - which tend to concentrate in cities (Naldi et al., 2015). Does it mean that rural settlements are disadvantaged and to what extent? Like the smart city, a smart village should also be based on using digital technologies. In the literature, the concept is mainly related to the rural infrastructure in developing countries, most often to the production and the use of electric energy from local sources (e.g., Ho et al., 2014) and to an application of information technologies for agricultural management often in a relation to the climate change (Taylor, 2017), or to support the creative industries (Townsend et al., 2017). Sometimes, the contribution to smart villages is seen in the mass use of GIS technologies for rural planning and management (Wang et al., 2017). However, also, in this case, a complex system aimed at an improvement of the rural livelihoods (Wallace et al., 2017) should be taken into account.

Other authors (Hudson, 2013) prefer the accessibility of information including the most peripheral villages. In this way, all the people could be included in positive (but also negative) global trends. A problem of using digital technologies in the rural space has been identified by Phahlamohlaka et al. (2014): Individual technologies are often applied separately while a complex approach could be much more efficient. Of course, new sources of exclusion could arise which would concern the people without access, knowledge or any interest to use the internet.

Ranade, Londhe, and Mishra (2015) indicate the following aspects of smart villages in India: smart infrastructure, smart service delivery, smart institutions, and smart technology and innovations. Shukra (2016) speaks about the integrated planning of rural communities by means of digital technologies aimed at development, local businesses, improving education, health, and welfare, preventing social exclusion of seniors and disabled people and the democracy and participation. In developing countries, the countryside is usually underdeveloped in comparison with cities, remote and often hardly accessible by transport infrastructure as well as not connected with networks of the technical infrastructure. It follows that the concept of smart villages is directed towards the abilities of digital technologies to overcome these shortcomings as a rule.

What is the role of digital technologies in the countryside of developed countries and how the concept of a European smart village should be created? Visvizi and Lytras (2018) tried to delimit the conceptual boundaries of the smart village. They justified a different approach to the villages from the cities. According to the Bled Declaration, the concept of a smart village should include: precision farming, various digital platforms (e-learning, e-health, e-administration, transport, gastronomy, social services, retail), shared economy, circular economy reducing waste and saving resources, bio-based economy, renewable energy, rural tourism, social innovations in rural services and entrepreneurship. The concept of smart village in this approach (including the differences against smart city concept) has been elaborated by Guzal-Dec (2018). She 
suggests following six basing dimensions of smart: management, economy, mobility, natural environment, society, quality of life.

The various aspects of smart villages that have been enumerated suggest that the idea of smart villages can be connected with the concept of sustainability with its three pillars (social, economic and environmental). It indicates a wide interdisciplinary reach of smart village research and its applications. Unfortunately, Czech research literature does not pay much attention to digital technologies for rural development. The contemporary national literature in the field is based mostly in the form of Bachelor and Diploma theses or research reports. This suggests that the issue mainly engages the youngest generation of researchers.

We will pay our attention to the individual pillars of sustainability in a slightly modified form. The social pillar can be seen as a problem of combatting exclusion by means of digital technologies. The economic pillar will be discussed as a potential of a work from home using online technologies. The environmental pillar touches upon our research as a clever infrastructure for solving environmental problems. The fourth pillar, directed on intelligent management of rural municipalities is also taken into account.

\section{South-Moravian rural settlements}

The South-Moravian region, bordering with Austria and Slovakia is situated in southern (more rural) half of the Czech territory and its eastern part - most distanced from the highly developed European countries. This disadvantage is partly balanced by the city of Brno which is an important second-order city with developed educational and commercial functions. The region is situated on the transit European routes from the North to the South and from the North-West to the SouthEast.

The South-Moravian settlement system consists of a big city Brno, five medium-size district towns, two dozens of small towns and about 650 rural communes (Vaishar et al., 2011). These rural communes take $44 \%$ of inhabitants and $96 \%$ of the area of this NUTS3 region. About a third of the South-Moravian rural area has a population density under 50 persons per $\mathrm{km}^{2}$, the second third the density between 50 and 100 inhabitants $/ \mathrm{km}^{2}$ and the remaining third over 100 persons per $\mathrm{km}^{2}$. The agricultural land takes $64 \%$, the forest land $26 \%$ of the area.

The closest town is accessible for $93 \%$ of the rural population in up to 30 minutes. The territory is fully covered with the integrated system of public transport, ensuring frequent accessibility in any place of the region. In the region, the urban-to-rural migration prevails over the rural-to-urban migration. The problem consists mainly of a limited structure in formal education level of the rural population which is still more adapted more to the productive economy in comparison with cities. In agriculture, forestry, and fishery, about $4.5 \%$ of rural population were employed (2011), whereas $29 \%$ were engaged in industry. From this, it follows that the South-Moravian rural population does not depend on agriculture and its development. The unemployment rate at 3.9\% is slightly above average.

The South-Moravian countryside could be divided into the following areas: (a) the suburban area in the surroundings of the city of Brno with relative positive social indicators but with slowly losing rural character, (b) fertile and well-accessible countryside of the South-Moravian lowlands with the culture of wine, (c) peripheral countryside of highlands including inner periphery represented by Bohemian-Moravian Highlands and the borderland with Slovakia (White Carpathian Mts.), (d) borderland with Austria where the population was exchanged after the WWII, and thus the long term development of the social system has been interrupted.

\section{The potential of an application of the smart village concept in South- Moravian villages}

The fight against the exclusion of certain population groups seems to be probably the most important social problem in rural areas. The care for seniors, disabled people, mothers with small children and other marginalised groups is the main task of the state administration in rural areas because these people are hardly able to help themselves without any assistance. It is important especially in the smallest and most peripheral villages with very limited public and commercial 
services. Under Czech conditions, where people traditionally rely on the state instead of a family, the importance of this factor is increasing.

The question is how the application of the smart village concept could help to solve the problem of rural exclusion. Digital technologies such as cellular phones and the internet could ensure regular contacts of marginalised people with the World and eventually to call for help. The question is to what extent the rural space is covered with the signal of operators and with fast internet. At the beginning, the introduction of ITC into rural areas in Czechia relied upon the dense network of public libraries that can be found almost in every rural settlement.

The accessibility by the internet with minimum speed of $30 \mathrm{Mbit} / \mathrm{s}$ in 2016 is in Fig. 1. In the SouthMoravian region with its large villages and relatively flat landscape, the coverage is aboveaverage. The policy aim is to cover the whole territory by the end of 2020. However, the coverage of the remaining area should require relatively big expenses but would bring only a small number of customers. Nevertheless, at least theoretically, the problem of coverage will not exist in the near future. Of course, some problems with quality, capability and price of the connection persist. In addition, there is the possibility of coverage of problematic European areas with fast internet through satellite technology, which is under preparation (Giggenbach et al., 2015).

The second question is, to what extent are the marginal people familiar with using these instruments. Correa and Pavez (2016) argue that the urban/rural gap in the use of digital technologies remains strong using an example from Chile. It is sometimes spoken about double exclusion when marginal people cannot use the digital technologies because of a low educational level (Resta and Laferrière, 2015), age (Rasi and Kilpeläinen, 2016) or other reasons. E.g. Park (2017) shows on the Australian example, how the remoteness and social remoteness could create double jeopardy. The paradox is that rural communities are most in need of improved digital connectivity to compensate for their remoteness, but they are least connected and included (Salemink et al., 2017).

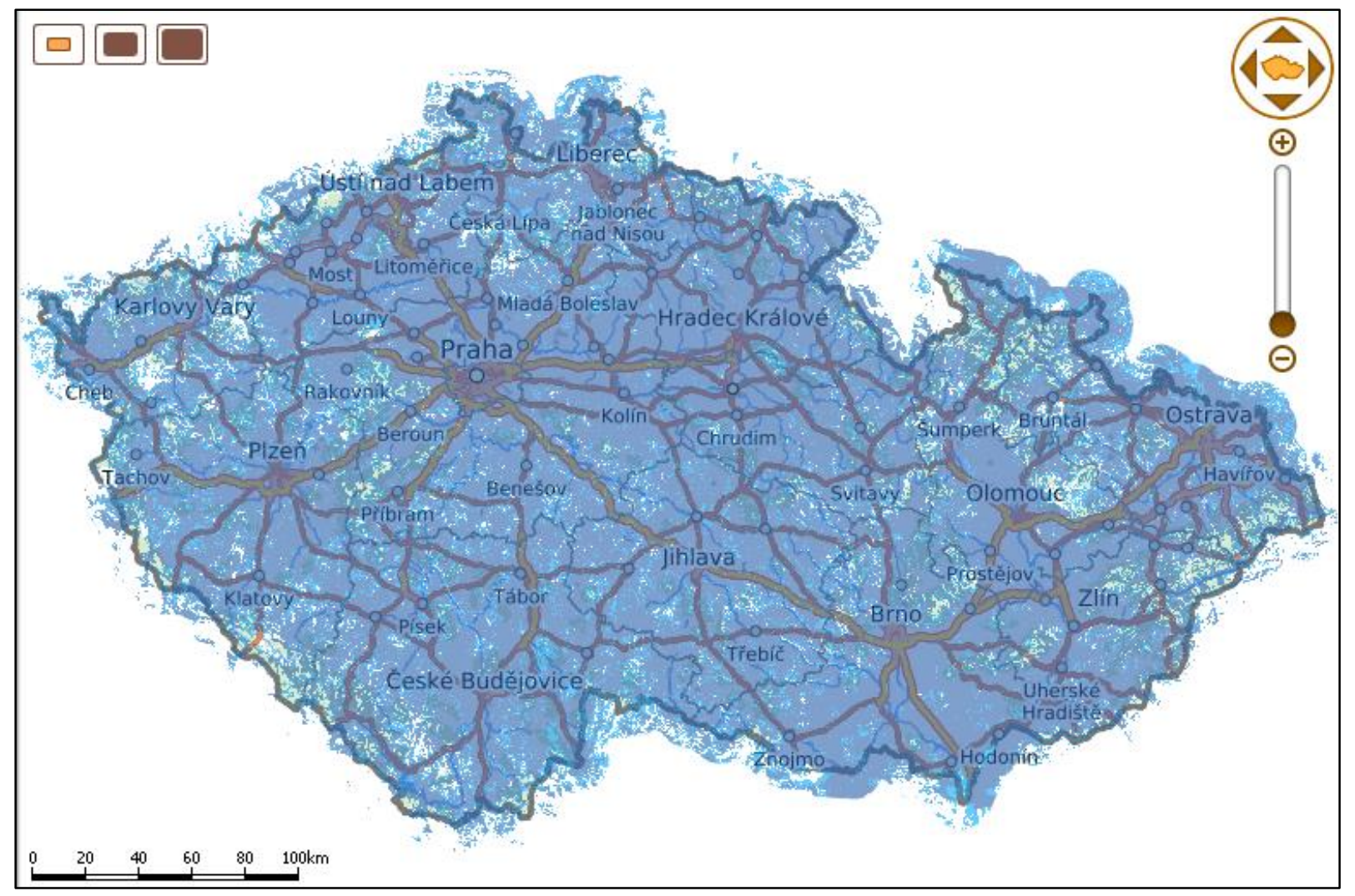

Fig 1. Map of the coverage of the Czech territory by Vodafone operator in August 2019. Source: Czech Telecommunication Office 
In the South-Moravian Region, problems could be expected in the most peripheral micro-regions, which can be found in the south-western part and the most eastern part of the region. In the surroundings of Brno and the district towns, the average education and skills with IT technologies are probably sufficient (see Table 1).

Tab 1. Coverage of individual districts of the South-Moravian Region by public internet in August 2019. Source: Czech Telecommunication Office Prague 2019

\begin{tabular}{|l|c|c|c|c|}
\hline District & Area [km²] & Coverage [\%] & Population [thousand] & Coverage [\%] \\
\hline Blansko & 862 & 94.6 & 106 & 98.6 \\
\hline Brno City & 230 & 98.8 & 379 & 100.0 \\
\hline Brno Land & 1,498 & 93.9 & 204 & 98.9 \\
\hline Břeclav & 1,044 & 97.6 & 114 & 100.0 \\
\hline Hodonín & 1,103 & 96.5 & 156 & 99.9 \\
\hline Vyškov & 876 & 91.8 & 89 & 99.5 \\
\hline Znojmo & 1,596 & 95.6 & 113 & 99.4 \\
\hline South-Moravian Region & 7,208 & 95.2 & 1,161 & 99.5 \\
\hline
\end{tabular}

Internet literacy does not lie only in the ability to control basic functions but also in using a wide spectrum of services offered. Many users perceive IT technologies as a source of entertainment playing games, using social networks, maybe even shopping. However, the education level is important for more sophisticated use. It is also a question whether and to which extent IT technologies could substitute face-to-face contacts or whether their function lies in the potential of an added value to physical contacts. A threat of using internet instead of physical contact consists of the development of some dependency. What follows is that it is not sufficient to rely solely upon the IT technologies for social rural inclusion.

Since the 1970s, there has been a widespread debate on using the information and communication technologies for the decentralization of work. However, the expectations have not yet been fulfilled (Clark, 2018). Mass use of information technologies for the labour market oscillates between two standpoints. On one side, innovation technologies have a tendency to be concentrated in big cities. On the other side, the transfer of information can substitute (to a certain extent) physical transport. It could enable the creation of skilled jobs in the periphery (Reinöhlová, 2005). The potential of the homeworking, teleworking or home office represents the economic pillar of smart villages (Frantíková et al., 2017).

There remains a problem however, that the indigenous rural people in Czechia are mostly educated for productive branches of the economy in primary and secondary sectors. They have an employee psychology, which divides their lives between work in an industrial or agricultural company and work at home - directed mostly towards caring for their homes and families. Family enterprises in services, handicrafts or agriculture use IT in only the simplest way. One example is that the implementation of the electronic sales records has evoked strong resistance and has even led some politicians to suggest that this is a reason for the abandonment of services to small villages.

Therefore, the possibility of teleworking is more attractive to migrants from cities to the rural space than for indigenous country people. The attitudes of employers to teleworking are sometimes constrained because they are partly losing control over employees and data. It seems to be more suitable in the case of experienced people who have created working habits and can provide a guarantee of accomplishment of tasks (Arvola, Tint and Kristjuhan, 2017). Thus, this way of 
working is used rather exceptionally. A bigger implication of teleworking in rural areas would require a shift altogether in corporate culture (Vitola and Baltina, 2013).

The potential of ICT for controlling infrastructure is promising but not yet frequently used. It could concern technical infrastructure (transport, waste management, lighting, water or heat supply, energy supply, librarian systems, etc.), sometimes in cooperation with GIS, remote sensing and GPS technologies. The ICT technologies could find its applications also in social services like retail (e-commerce, e.g., Jalali et al. (2011), hospitality service (e.g., Reino et al., 2011), health care (telemedicine, see e.g., Ruxwana, 2010), education or tourist information. It is seen from the citations that ICT is often applied in developing countries where physical accessibility is sometimes much more difficult than in developed countries. However, the insufficiency of some services in small villages could be solved partially by using digital technologies also in Moravia.

Concerning the South-Moravian Region, e.g., the Integrated Transport System of the SouthMoravian Region, which covers the complete territory of the region and some transboundary municipalities of neighbouring regions, applies modern approaches of the digital communication with passengers (purchase of tickets through SMS, track the current position of the vehicle on the line, sending information to e-mails on request, etc.). Unfortunately, the attempts in this direction are often isolated ones.

A very important benefit of digital technologies is seen in the use of ICT in communication between municipalities (or other bodies) and citizens. Traditional municipal radio, usual in Czech villages, is being substituted with a network of SMS and e-mail messages step-by-step. Warning systems in cases of natural (floods) or man-made disasters (e.g. fires, industrial accidents) represent a prospective function of ICT. A possibility of a call for assistance is important especially for lonely older people in cases of accidents or illnesses.

Smart systems are also prospective in the field of e-government, e-participation (Cecchini and Plaisant, 2015) and participatory planning because they enable two-way communication. Municipalities can obtain better feedback, whereas citizens can obtain immediate information and the possibility to express their views. In such a way, relations between the municipality and inhabitants take on a new dimension. Mapping illegal dumpsites (Kubásek, 2013) is one of the applied ways of citizens' participation in environmental governance in rural municipalities.

Of course, it is necessary to overcome the current mechanisms for communication in municipal councils. Bachmann and Zubr (2014) found that $97 \%$ of Czech villages own and operate their web pages. On the other side, on these web pages, the name of the mayor was mentioned in $94 \%$ of cases, his/her telephone contact in 54\%, their e-mail address in $30 \%$ cases and contacts to other representatives of the municipality in $7 \%$ of cases only. It means that there is still a tendency of public administration towards one-way top-down information for citizens in many cases.

A huge infrastructure has been built in the last years. Telecommunication networks, the system of CzechPoints $^{2}$, a communication through data-boxes, various registers, etc. Up until now this infrastructure serves mainly to the state and its bodies. However, it is prepared also to serve citizens as far as they can and will to work with ICT.

\footnotetext{
${ }^{2}$ Czech Point - a place (usually a post office or notary) from which a citizen can communicate with the state (to extract statements from the state administration registers, to file with the state administration, to handle data boxes etc.)
} 


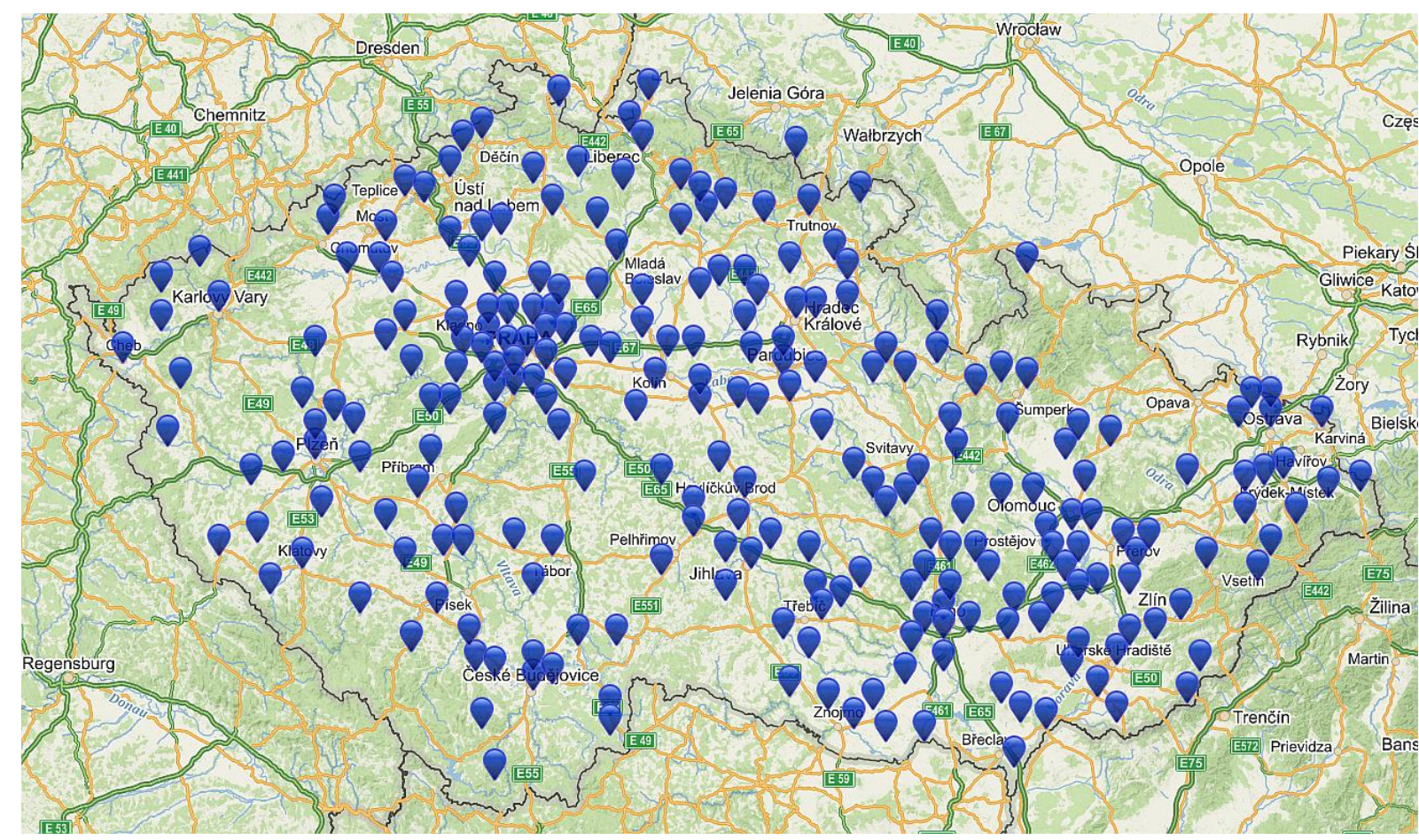

Fig 2. Czech Points (places from which a citizen can communicate with the state in a digital form). Source: Ministry of Interior of the Czech Republic

\section{Are Moravian villages underway to their smart future?}

Among the barriers to the application of the smart village concept, it is possible to name the rural conservatism and not very friendly approach to innovations, physical distance from poles of the development, insufficient financial sources necessary for the implementation of the concept, lower educational level of the rural population (compare with Nagy et al., 2018).

The education level of rural people (except for suburbia) is generally lower than those in cities. When increasing the educational potential by support of higher formal education (complete secondary, university), educated people often abandon rural settlements and look to pursue their careers in cities. Perhaps, the targeted support of abilities and competencies (both technical and social) in the use of ICT technologies in the rural space could be the right way on how to keep skilled people in the countryside.

It is clear that the main problem of the coverage of rural areas with high speed internet is a low population density in mountain territories. To cover the remainder of the area of the state (the lastmile telecommunications, Nandi et al., 2016) is thus hardly efficient. However, the population of the uncovered areas forms only a small share of the inhabitants. Probably, it is acceptable after all to have some territories without any coverage to have some rest territories of freedom from ICT. Indeed, satellite phones can fill this gap in necessary cases.

\section{Conclusions}

It is possible to state the following:

1. There is hardly any technological nor economic barrier for using information technologies in the rural areas. Although the coverage is not as dense as in cities, a large majority of the population has access to IT networks. The purchase price of hardware and software enables the use of IT for common people - especially if it should be as a means of working.

2. On the other side, the lower educational level and conservatism of rural population prevents intensive use of IT for practical purposes. The people use them rather as a means of entertainment, shopping, and social networks. The approach to IT technology depends also on the age structure - younger people are more familiar with IT. However, rural settlements (except the very small ones of less than 200 inhabitants) do not have populations older than 
in the cities, so this factor does not play any role in the relation of urban-rural difference in IT applications as it would in some other countries.

3. The on-line homework could be more attractive for urban-rural migrants who could connect living in the rural milieu with an attractive and well-paid online job. However, it does not seem that on-line connection is sufficient for them to be able to manage a full-fledged job. Also personal contacts have to be kept as a rule and these require presence in the workplace.

4. We are of the opinion that the improvement in the qualification level of rural people could consist of an improvement of IT literacy in relation to rural development - instead of an increase in merely formal education.

Speaking about the smart village, it is necessary to take into account that not only direct and measurable items are important. It seems that indirect benefits like self-realization of rural people or social cohesion could play more important role than the technology from the viewpoint of rural development (Gomez and Pather, 2017, Wallace et al. 2017). Perhaps it is this which makes the smart village important.

\section{Acknowledgment}

The paper was elaborated within the specific research of the Department of Applied and Landscape Ecology, Faculty of AgriSciences of the Mendel University in Brno.

References

[1] Arvola, R., Tint, P., Kristjuhan, U. (2017). Employer attitude towards telework in real estate sector. Economic Science for Rural Development Conference Proceedings 46, 15-22.

[2] Bachmann, P., Zubr, V. (2014). What affects the information provided on the web? Case of Czech rural municipalities. Acta Universitatis Agriculturae et Silviculturae Mendeliana Brunensis 62(6), 1221-1231. DOI: 10.11118/actaun201462061221.

[3] Cecchini, A., Plaisant, A. (2015). Better decisions for better quality of life: the potential of rural districts supported be e-governance tools. In Gervasi, O. et al., eds., Computational Science and its Applications - ICCSA 2015 (pp. 577-592). Cham: Springer.

[4] Clark, M. A. (2018). Teleworking in the countryside. London: Routledge.

[5] Correa, T., Pavez, I. (2016). Digital inclusion in rural areas: a qualitative exploration of challenges faced by people from isolated communities. Journal of Computer-Mediated Communication 23(3), 247-263. DOI: 10.1111/jcc4.12154.

[6] Frantíková, Z., Vlčková, M., Vrchota, J., Sládek, J. (2015). Comparison of homeworking in the Czech Republic and Spain. In Cingula, M., Przygoda, M., Detelj, K., eds., Economic and Social Development (pp. 693-700). Varaždin Development and Entrepreneurship Agency.

[7] Giggenbach, D., Lutz, E., Poliak, J., Mata-Calvo, R., Fuchs, C. (2015). A high throughput satellites system for serving whole Europe with fast internet service, employing optical feeder links. In Broadband Coverage in Germany (not paged). Berlin: VDE Verlag.

[8] Gomez, R., Pather, S. (2017). ICT evaluation: Are we asking the right question? The Electronic Journal of Information Systems in Developing Countries 50(1), 1-14. DOI: 10.1002/j.1681-4835.2012.tb00355.x.

[9] Guzal-Dec, D. (2018). Intelligent development of the countryside - the concept of smart villages: assumptions, possibilities and implementation limitations. Economic and Regional Studies 11(3), 32-49. DOI: 10.2478/ers-2018-0023.

[10] Ho, W. S., Hashim, H., Lim, J. S. (2014). Integrated biomass and solar town: Concept for a smart eco-village in Iskandar Malaysia. Renewable Energy 69, 190-201. DOI: 10.1016/j.renene.2014.02.053. 
[11] Hudson, H. (2013). From rural village to global village. New York: Routledge. DOI: $10.4324 / 9780203933138$.

[12] Jalali, A. A., Okhovvat, M. R., Okhovvat, M. (2011). A new applicable model of Iran rural ecommerce development. Procedia Computer Science 3, 1157-1163. DOI: 10.1016/j.procs.2010.12.187.

[13] Kubásek, M. (2013). Maping illegal dump sites in the countryside. In Fialová, J., Kubíčková, H., eds., Public Recreation and Landscape Protection - with Man Hand in Hand: Conference Proceedings (pp. 82+). Brno: Mendel University.

[14] Monzon, A. (2017). Smart cities concept and challenges. Bases of the assessment of smart city projects. In 2015 International Conference on Smart Cities and Green ICT Systems (not paged). Piscataway, NJ: IEEE Xplore.

[15] Nagy, K., Kaposzta, J., Varga-Nagy, A. (2018). Is ICT smartness possible development way for Hungarian rural areas? Engineering for Rural Development 17, 463-468. DOI: 10.22616/ERDev2018.17.N041.

[16] Naldi, L., Nilsson, P., Westlund, H., Wixe, S. (2015). What is smart rural development? Journal of Rural Studies 40, 90-101. DOI: 10.1016/j.jrurstud.2015.06.006.

[17] Nandi, S., Thota, S., Nag, A., Divyasukhananda, S., Goswami, P., Anavindakshan, A., Rodriguez, R., Mukherjee, B. (2016). Computing for rural empowerment: enabled by lastmile telecommunications. IEEE Communication Magazine 54(6), 102-109. DOI: 10.1109/MCOM.2016.7498095.

[18] Neirotti, P., de Marco, A., Cagliano, A. C., Mangano, G., Scorrano, F. (2014). Current trends in smart city initiatives: some stylised facts. Cities 38, 25-36. DOI: 10.1016/j.cities.2013.12.010.

[19] Park, S. (2017). Digital inequalities in rural Australia: a double jeopardy of remoteness and socxial exclusion. Journal of Rural Studies 54, 399-407. DOI: 10.1016/j.jrurstud.2015.12.018.

[20] Phahlamohlaka, J., Dlamini, Z., Mnisi, T., Mashiane, T., Malinga, L. (2014). Towards a smart community centre: SEIDET digital village. In: Kimppa K., Whitehouse D., Kuusela T., Phahlamohlaka J. (eds) ICT and Society. Berlin/Heidelberg: Springer, pp. 107-121.

[21] Ranada, P., Londhe, S., Mishra, A. (2015). Smart villages through information technology need of emerging India. International Journal of Information Technology 3(7), 1-6.

[22] Rasi, P., Kilpeläinen, A. (2016). Older people's use and learning of new media: a case study on remote rural villages in Finnish Lapland. In Zhou, J., Salvendy, G., eds., Human Aspects of IT for Aged Population (pp. 239-247). Springer Switzerland.

[23] Reino, S., Frew, A. J., Albacete-Sáez, C. (2011). ICT adoption and development: issues in rural accommodation. Journal of Hospitality and Tourism Technology 2(1), 66-80. DOI: $10.1108 / 17579881111112421$.

[24] Reinöhlová, E. (2005). Informační a komunikační technologie pro rozvoj periferních oblastí. In Novotná, M., ed., Problémy periferních oblastí (pp. 36-43). Praha: Karlova univerzita.

[25] Resta, P., Laferrière, T. (2015). Digital equity and intercultural education. Education and Information Technologies 20(4), 743-758. DOI: 10.1007/s10639-015-9419-z.

[26] Ruxwana, N. L., Herselman, M. N., Conradie, D. P. (2010). ICT applications as a e-health solutions in rural healthcare in the Eastern Cape province of South Africa. Health Information Management Journal 39(1), 17-29. DOI: $10.1177 / 183335831003900104$.

[27] Salemink, K., Strijk, D., Bosworth, G. (2017). Rural development in the digital age: A systematic literature review on unequal ICT availability, adoption, and use in rural areas. Journal of Rural Studies 54, 360-371. DOI: 10.1016/j.jrurstud.2015.09.001. 
[28] Shukra, P. Y. (2016). The Indian smart village: foundation for growing India. International Journal of Applied Research 2(3), 72-74.

[29] Taylor, M. (2017). Climate-smart agriculture: what is it good for? The Journal of Peasant Studies 45(1), 89-107. DOI: 10.1080/03066150.2017.1312355.

[30] Townsend, L., Wallace, C., Fairhurst, G. \& Anderson, A. (2017). Broadband and the creative industries in rural Scotland. Journal of Rural Studies 54: 451-458. DOI: $10.1016 /$ j.jrurstud.2016.09.001.

[31] Vaishar, A., Št’astná, M., Vavrouchová, H., Stejskal, B., Hlisnikovský, L., Jakešová, L., Kniezková, T., Kozáková, H., Lipovská, Z., Marciánová, G., Náplavová, M., Novotná, K., Oštádalová, Z. (2011). Současný stav a vývojové tendence jihomoravského venkova. Brno: Mendelova univerzita v Brně.

[32] Visvizi, A., Lytras, M. D. (2018). It's not a fad: Smart cities and smart villages research in European and global contexts. Sustainability 10(8), 2727. DOI: 10.3390/su10082727.

[33] Vitola, A., Baltina, I. (2013). An evaluation of the demand for telework and smart work centres in rural areas: a case study from Latvia. European Countryside 5(3), 251264. DOI: 10.2478/euco-2013-0016.

[34] Wallace, C., Vincent, K., Luguzan, C., Townsend, L. \& Beel, D. (2017): Information technology and social cohesion. A tale of two villages. Journal of Rural Studies 54, 426-434. Doi: 10.1016/j.jrurstud.2016.06.005.

[35] Wang, K., Zhou, W., Xu, K., Liang, H., Yu, W., Li, W. (2017). Quantifying changes of villages in the urbanizing Beijing metropolitan region: Integrating remote sensing and GIS analysis. Remote Sensing 9(5), 448. DOI: 10.3390/rs9050448.

[36] Zavratnik, V., Kos, A., Stojmenova-Duh, E. (2018). Smart villages: Comprehensive review of initiatives and practices. Sustainability 10(7), 2559. DOI: 10.3390/su10072559.

[37] Zubizaretta, I., Seravalli, A., Arrizabalaga, S. (2016). Smart city concept. What it is and what it should be. Journal of Urban Planning and Development 142(1). DOI: 10.1061/(ASCE)UP.1943-5444.0000282. 